\title{
A Study on Media Literacy of Industrial Education
}

\author{
Kanyuma Jitjumnong, Pasapitch Chujai, and Noritsugu Kamata
}

\begin{abstract}
Even in our information-oriented society, school education has not been able to fully utilize the media. In order to secure the knowledge of electrical power generating to students, it is necessary to consider how to use media more effectively. To that end, we aim to develop future educational activities after organizing and grasping information literacy, media literacy, technology literacy, etc... in current school education. In addition, in the process of practicing the presentation making full use of media, the students aim to foster their thinking, judgment and expression.
\end{abstract}

Index Terms-Media Literacy, power technology, education content, information literacy, technology literacy.

\section{INTRODUCTION}

In order to secure the knowledge of electrical power generation to students, it is necessary to consider how to use the media more effectively. To that end, we aim to develop future educational [1] activities after organizing and grasping information literacy, media literacy [2], and technology literacy in current school education. Power Technology teaching level in the current high school course of study is poor. In order to acquire knowledge on power technology, in order to develop skills and positive attitudes and put those in use, in order to handle the basic principles, methods, configurations and characteristics of power generation dealing with solar power and wind power we should use media [3]. The content of the current course of study is insufficient. There are various electrical power generation methods for and research is also in progress. There is geothermal power generation, biomass power generation [4], [5] solar thermal power generation [6] and tidal power generation [7], [8]. In Japan, since 2002 (for elementary, junior high and high school students) "Informational education" was adopted in "total study time" in media literacy, without being confused by the media, in order to acquire the power to survive and provide information to society. Complex abilities consist of specific elements of media literacy. There are three elements of media literacy. The first is the ability to read the media independently, the ability to understand the characteristics of each media who transmits the information and critically analyzes, evaluate, and examine the information transmitted from the media in a social context, the ability to choose. The second is the ability to access and utilize media (the ability to select, manipulate, and actively utilize media devices). The third one is the

Manuscript received July 31, 2019, revised November 20, 2019.

The authors are with the Electrical Technology Education Department, Faculty of Industrial Education and Technology, King Mongkut's University of Technology Thonburi, Bangkok, Thailand (e-mail: kanyuma.jit@kmutt.ac.th,_ pasapitchchujai@gmail.com, noritsugu.kamata@mail.kmutt.ac.th). ability to create communication through media (Interactive) and the ability to communicate (especially with information readers). From these things, I will organize and judge critical thinking power. Information literacy [9], digital literacy and technology literacy can help cultivate the ability to process, understand, express and use data. Furthermore, students can improve their knowledge, understanding, thinking ability, judgment ability and expressive ability in the field of specialization and form critical thinking ability.

\section{FLOW OF EARNING}

The studying level in Japanese high school, in the department of power technology in the field of power technology, demand and supply of power, hydropower [10], thermal power generation [6], nuclear power generation [11], new energy generation [12], and summary of new energy generation is considered to be inadequate. Regarding new energies, it is necessary to handle the basic principles, methods, configurations and characteristics of electrical power generation. It is important to widely recognize the importance and necessity of the safety of power plants and the quantity of power needed for daily life, to acquire and understand the basic matters. For that purpose, the use of audiovisual equipment and developmental learning will be required.

\section{Class PRACTICE}

First, I will explain the mechanism of power generation using coils and magnets. Then, I will continue about the mechanism of the hydroelectric power plant using a video. Finally, I will use audiovisual equipment and ask multiple questions searched for on the Internet [13]. We present NHK specific programs to School students as a reference material to make them think about the merits and demerits of the power plant [14]. Once, when teaching students about electrical power generation in power technology, they used to write on the whiteboard and learned from textbooks. It was difficult to understand the content, figures and photos written in the textbooks. Before learning about electrical power generation, schools only used textbooks, taking a questionnaire about the degree of understanding, testing the results, using the media to watch HNK education programs, and seeing the power company homepage, on the Internet. The results of conducting a post-class survey on power is summarized after learning, after browsing the photos and videos of the information that has been identified, rather than only teaching through textbooks, and by looking at photos and videos on the Internet. However, as a result of the quiz and the questionnaire after class, the level of understanding of the learner increased by the class using the media. 
In this study, the questionnaire about the degree of understanding before class and after class and the result of the test of the summary of power generation are shown in Fig 1 to Fig. 4.

Fig. 1 shows a summary of research about electrical power generation using a personal computer. It is difficult to teach the story of electricity with textbooks alone. The purpose is to increase the level of understanding of students using videos and photos using a computer.

Fig. 2 shows on the right side of the screen a photo of the questionnaire sheet after class. This time, we completed a questionnaire before and after class.

Next, we put together the surveyed contents in a worksheet. Students filled out the worksheet in the following order: thermal power [6], nuclear power and new energy [11] then discussed the results of each study in a group and made a presentation using the media.

Fig. 3 shows the picture of a student actually examining the summary of electrical power generation on the Internet and filling in a worksheet. By using a personal computer, he was able to find accurate information.

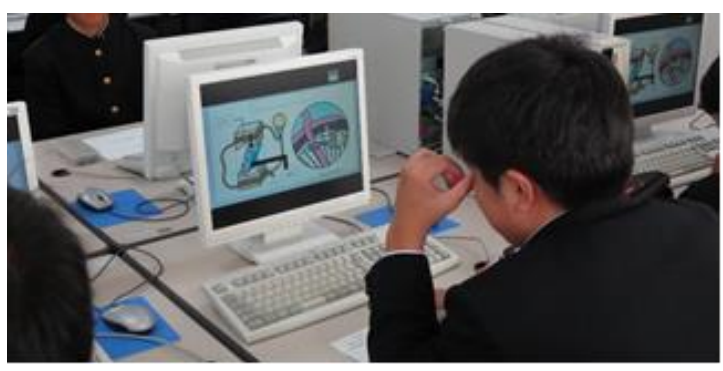

Fig. 1. State of class practice.

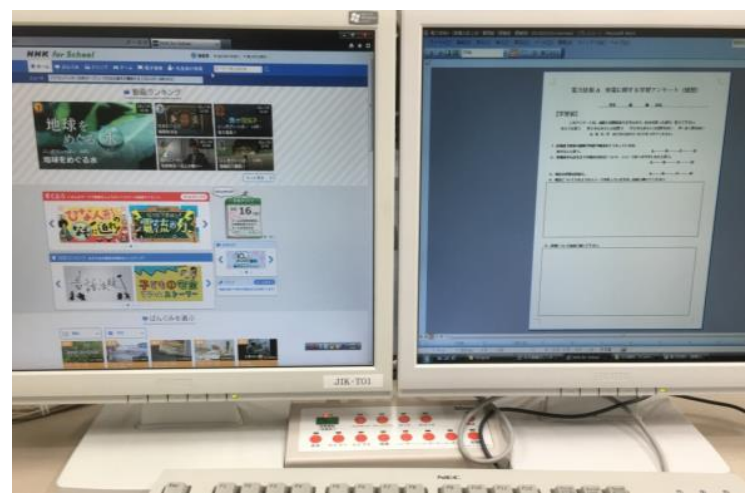

Fig. 2. Screen showing hydropower production and HNK education programs.

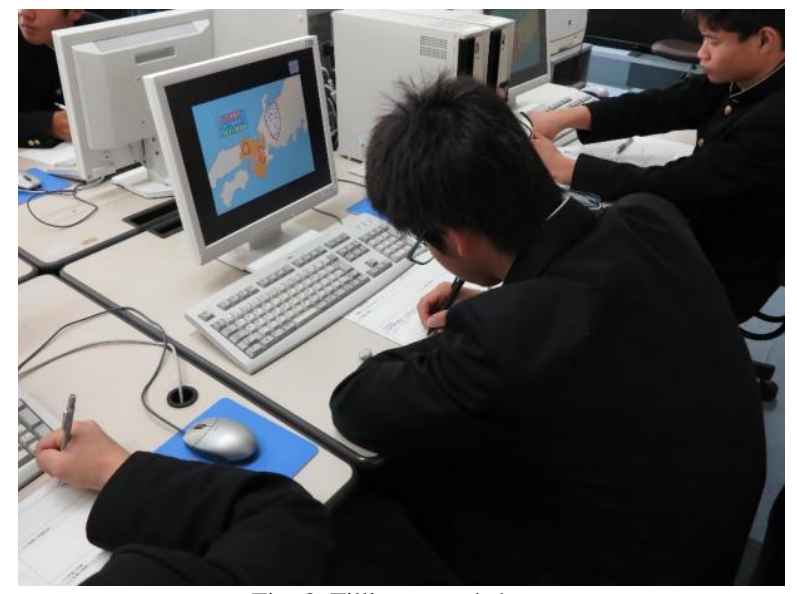

Fig. 3. Filling a worksheet.

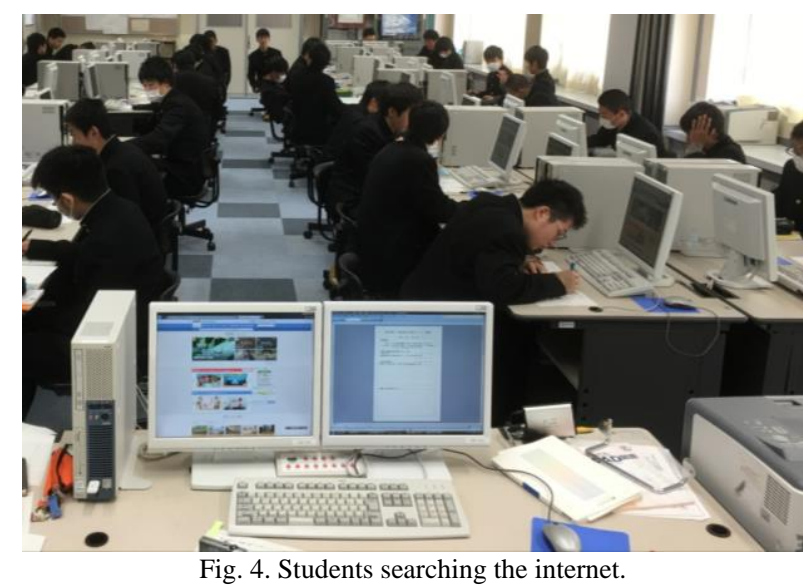

Fig. 4 Using the Internet helped the students to increase their knowledge, it made it easier for them to understand than learning from textbooks alone.

\section{AgGREgAted Results}

The total of persons in class A and class B was 77 people. We carried out tabulation for questionnaires.

First, in question (1), We want to know what is the structure of the power plant in Japan? As a result of asking the question, we compared before and after class, the results show in Fig. 5 and Fig. 6, respectively.

Fig. 5 shows that the characteristics and structure of thermal power generation, hydroelectric power generation, nuclear power generation, and new energy power generation are correct. As a result of listening to A-class students, they understood it better than just textbooks when using the Internet.

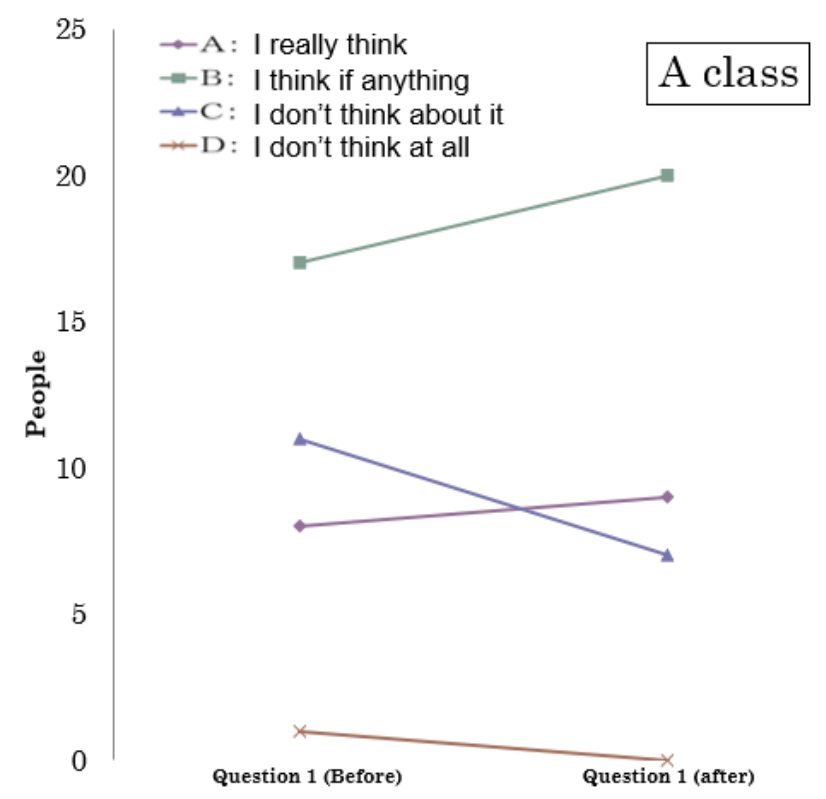

Fig. 5. Total graph before and after class A

Fig. 6 shows whether the characteristics and structure of thermal power generation, hydroelectric power generation, nuclear power generation, and new energy power generation are correct as well as Class A. As a result of asking questions to B-class students, we found that using the internet in addition to increasing the students' understanding of textbooks but also affects the understanding of other matters 
as well.

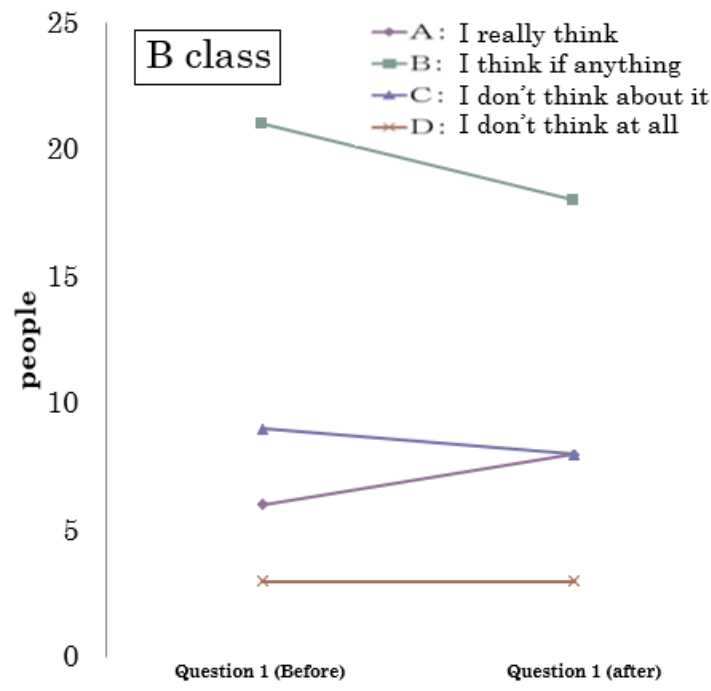

Fig. 6. Total graph before and after class B.

Fig. 7 and Fig. 8 show the content of Problem 2 which can explain the type and structure of the power plant. The answers to the questions were analyzed.

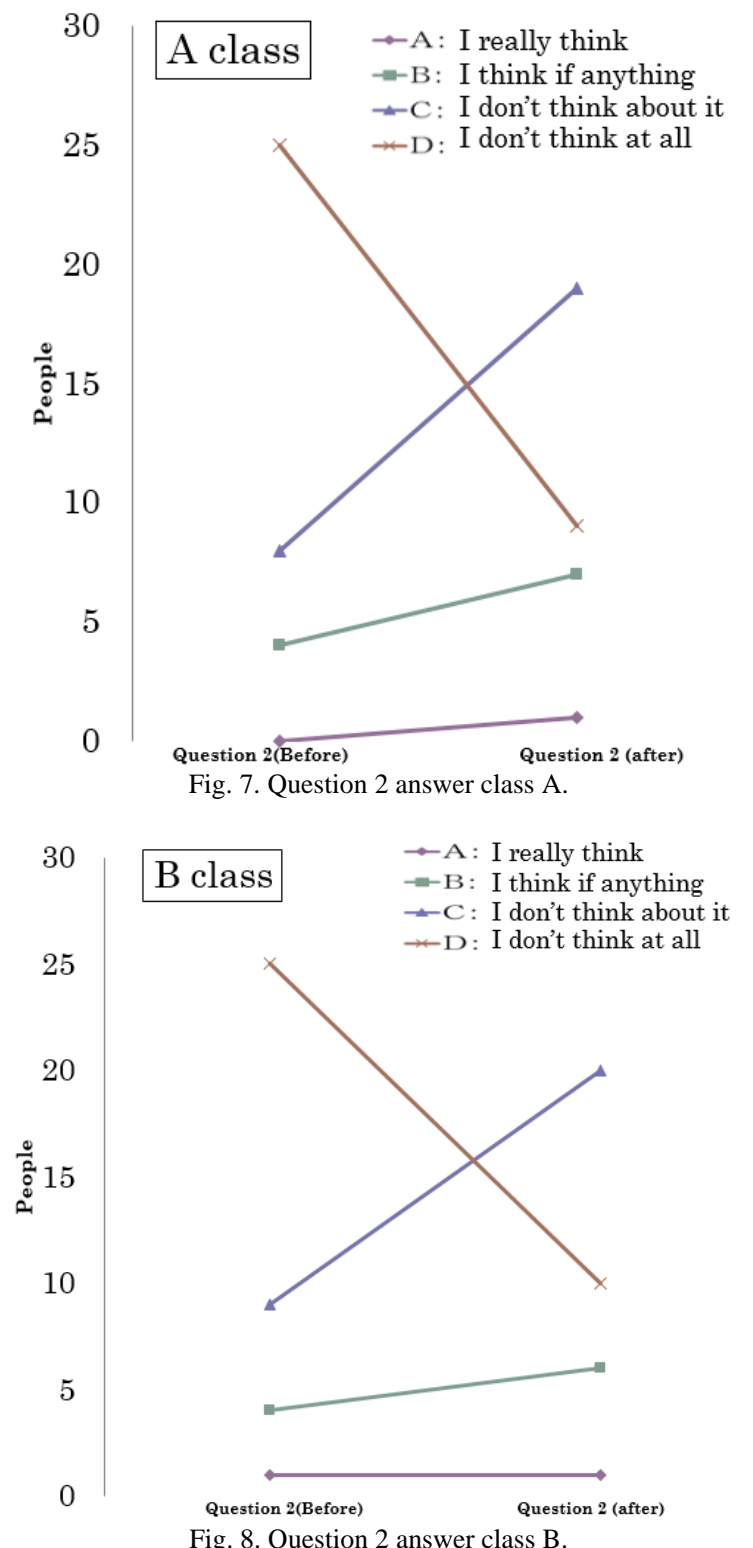

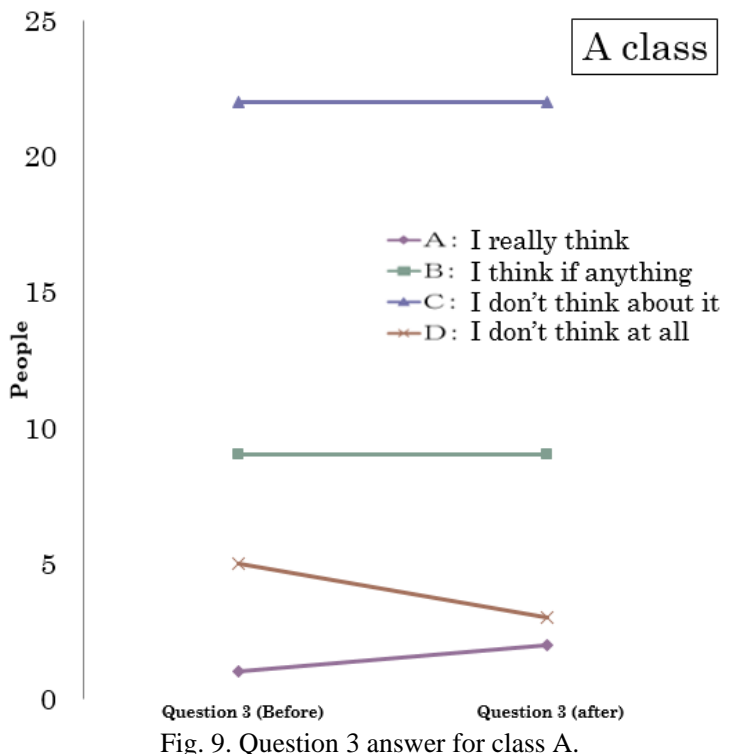

Fig. 7 shows that it is easier for students in class A to imagine the flow of electricity from the power plant to their home. It was a little easier to understand by studying on the Internet than understanding in a textbook-only class.

Fig. 8 shows that it is easier for students in class B to imagine the flow of electricity from the power plant to their home. Like Class A, it was a little easier to understand by studying on the Internet than understanding in a textbook-only class.

Finally, Fig. 9 and Fig. 10 show the results for "I am good at learning problem 3 electricity".

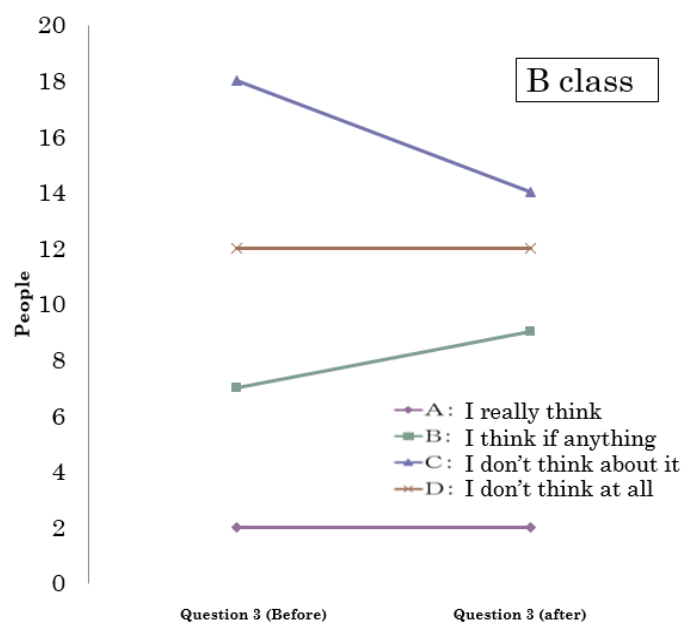

Fig. 10. Question 3 answer for class B.

Fig. 9 shows that if you ask students in class A that you are good at learning electricity, you can study the Internet, watch photos, watch videos, and not just take textbooks. I became more interested.

Fig. 10 shows that when you ask students in class B that they are good at learning electricity, they are studying the Internet, watching photos, watching videos, etc., rather than taking textbook classes. I was interested in electricity.

\section{AGgRegated MEAN AND Standard DEVIATION OF THE TEST}

Fig. 11 shows a test of 30 points. The first question is about 
the names of 10 power companies in Japan. The second question is about four types of power generation methods. The third asks about 6 new energy generation methods (generation suitable for the environment). The fourth is about the names of six power stations in the country. The results of the test were summarized.

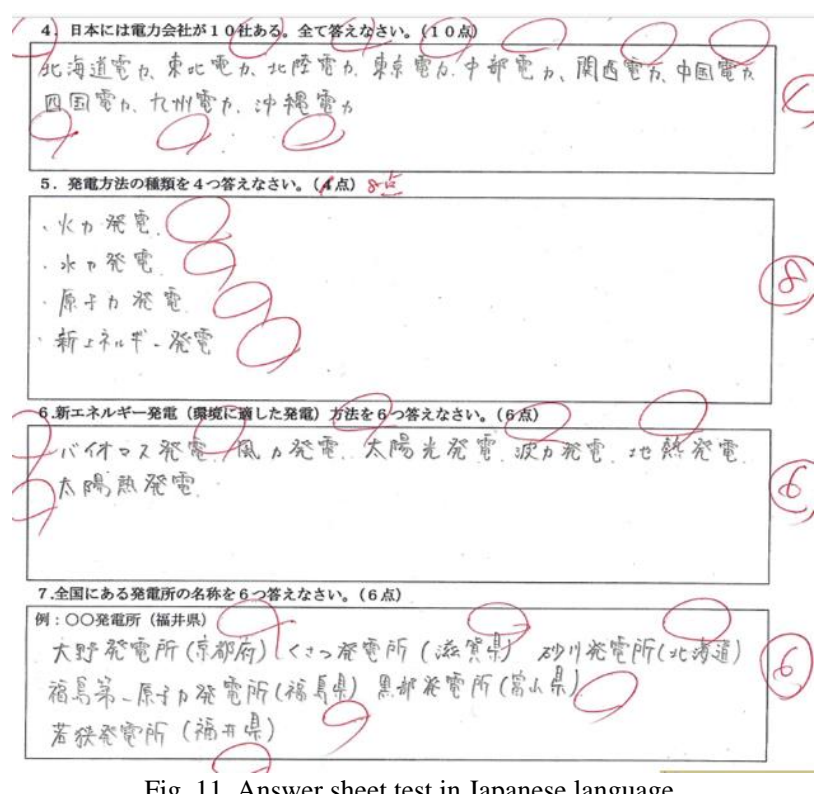

Fig. 11. Answer sheet test in Japanese language.

Fig. 11 shows the answer from the fourth question. There are 10 electric power companies in Japan. Please answer everything. I asked a question. Students can better understand by using the Internet to learn lessons with both $\mathrm{A}$ and B class textbooks. Next, as a fifth question, answer four different power generation methods. I asked a question. Compared with the score of the textbook alone after the class, the student's level of understanding improved when the test was conducted after studying on the Internet.

The sixth question asked what kind of power generation methods are available for new energy. In both Class A and Class $\mathrm{B}$, the results of the test to increase the level of understanding were obtained by using the Internet to display power plant photos and videos rather than using text to teach. Finally, as the seventh issue, we saw six power plants throughout Japan. The contents of both A and B classes are higher than the textbook class, and the tests show that looking through the internet and looking at photos improves understanding. Overall, the use of the Internet deepened students' understanding.

\section{Test Result Average And Standard Deviation}

Fig. 12 is the comparison made before and after the class. Before and after class, I used the internet and tested it, and the score for the test increased. It is thought that the degree of understanding has improved more than teaching with textbooks alone.

Fig. 12 shows the results of the A and B class tests. As shown in Fig. 11, the results of counting questions 4 to 7 for each class are tabulated and scored. The test average was calculated for each question. Compared to textbook-only classes in both Class A and Class B, the use of the media has helped students to become more knowledgeable and the test scores have increased.

\begin{tabular}{|c|c|c|c|}
\hline $\begin{array}{l}\text { A class (38people) } \\
\text { (Textbook only) }\end{array}$ & $\begin{array}{l}\text { Per person } \\
\text { Average } \\
\text { (30 full } \\
\text { marks) }\end{array}$ & $\begin{array}{c}\text { A class } \\
\text { (38people) } \\
\text { (Use Media) }\end{array}$ & $\begin{array}{c}\text { Per person } \\
\text { Average } \\
\text { (30 full marks) }\end{array}$ \\
\hline $\begin{array}{l}\text { Question }(4) \\
10 \text { points }\end{array}$ & 2. 0000 & $\begin{array}{l}\text { Question }(4) \\
10 \text { points }\end{array}$ & 8. 7368 \\
\hline $\begin{array}{l}\text { Question }(5) \\
8 \text { points }\end{array}$ & 4. 4211 & $\begin{array}{l}\text { Question }(5) \\
8 \text { points }\end{array}$ & 7. 7894 \\
\hline $\begin{array}{l}\text { Question }(6) \\
6 \text { points }\end{array}$ & 3. 1842 & $\begin{array}{l}\text { Question }(6) \\
6 \text { points }\end{array}$ & 5. 5263 \\
\hline $\begin{array}{l}\text { Question }(7) \\
6 \text { points }\end{array}$ & 0.8421 & $\begin{array}{l}\text { Question }(7) \\
6 \text { points }\end{array}$ & 1. 9736 \\
\hline Total average $(\mu)$ & 10.447 & Total average $(\mu)$ & 24.0263 \\
\hline $\begin{array}{c}\text { Standard deviation } \\
(\sigma)\end{array}$ & 4. 5184 & $\begin{array}{c}\text { Standard deviation } \\
(\sigma)\end{array}$ & 5.0215 \\
\hline $\begin{array}{l}\text { B class (39people) } \\
\text { (Textbook only) }\end{array}$ & $\begin{array}{c}\text { Per person } \\
\text { Average } \\
\text { (30 full } \\
\text { marks) }\end{array}$ & $\begin{array}{l}\text { B class } \\
\text { (39people) } \\
\text { (Use Media) }\end{array}$ & $\begin{array}{c}\text { Per person } \\
\text { Average } \\
\text { (30 full marks) }\end{array}$ \\
\hline $\begin{array}{l}\text { Question (4) } \\
10 \text { points }\end{array}$ & 2. 7692 & $\begin{array}{l}\text { Question }(4) \\
10 \text { points }\end{array}$ & 8.667 \\
\hline $\begin{array}{l}\text { Question (5) } \\
8 \text { points }\end{array}$ & 4. 0513 & $\begin{array}{l}\text { Question (5) } \\
8 \text { points }\end{array}$ & 7. 8461 \\
\hline $\begin{array}{l}\text { Question }(6) \\
6 \text { points }\end{array}$ & 2.8205 & $\begin{array}{l}\text { Question }(6) \\
6 \text { points }\end{array}$ & 4. 9743 \\
\hline $\begin{array}{l}\text { Question }(7) \\
6 \text { points }\end{array}$ & 0.4872 & $\begin{array}{l}\text { Question }(7) \\
6 \text { points }\end{array}$ & 1.9487 \\
\hline Total average $(\mu)$ & 10.128 & Total average $(\mu)$ & 23.4359 \\
\hline $\begin{array}{c}\text { Standard deviation } \\
(\sigma)\end{array}$ & 5.5306 & $\begin{array}{c}\text { Standard deviation } \\
(\sigma)\end{array}$ & 3. 6403 \\
\hline
\end{tabular}

Fig. 12. Comparison of before class (above) and after class (below) show aggregated mean and standard deviation of the test.

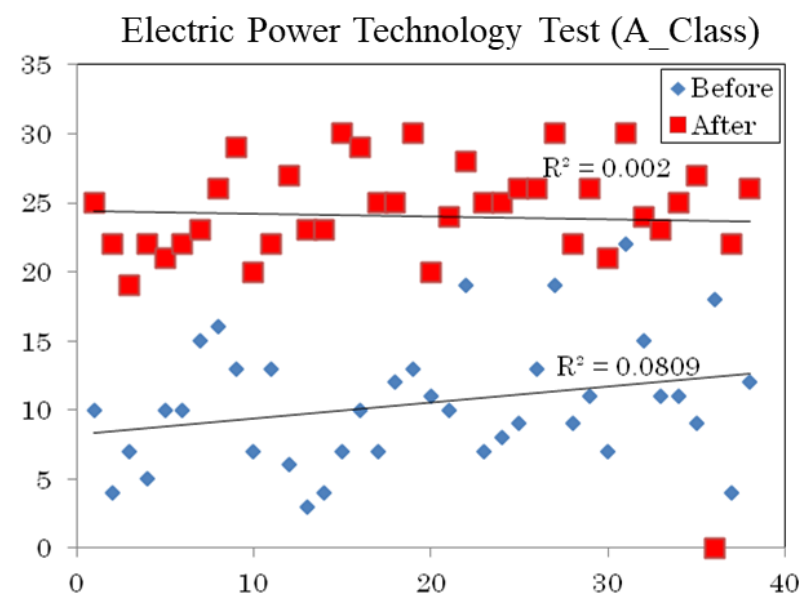

Fig. 13. Electric power technology test of before-after analysis (A Class).

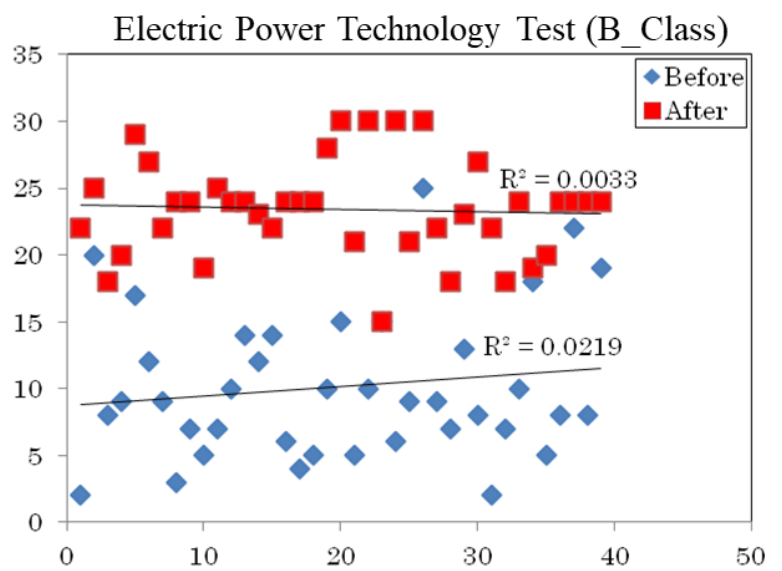

Fig. 14. Electric power technology test of before-after analysis (B Class). 
Fig. 13 compares the test results of power technology. The points scored in Fig. 12 are graphically represented. The list graph reveals that class $\mathrm{A}$ cannot be understood or understood before the class. Therefore, we found that using the media improves the student's overall understanding.

Fig. 14 compares the test results of power technology. The points scored in Fig. 12 are graphically represented. Like class A, class B revealed that knowledge and understanding were impossible before class. Therefore, a test was conducted after class. We found that using the media in the class increases the overall understanding of the students.

\section{CONCLUSION}

Using audio-visual equipment as an additional tool improved students' knowledge and increased their ability to think (critical thinking ability). Using media research tools also strengthened their understanding.

The results of the questionnaire answers showed that their level of understanding improved and deepened, strongly indicating that they are interested in the classes.

In the future, we plan to evaluate in a test format and analyze the learning effects of implementing classes in the electrical power field.

\section{CONFLICT OF INTEREST}

In this research, there is no conflict of interest. We declare that "The authors declare no conflict of interest".

\section{AUTHOR CONTRIBUTIONS}

The works of each author in this work are as follows:

Kanyuma Jitjumnong and Pasapitch Chujai are consultants and give advice about techniques, methods to be used in the process of the recommender system. Also, Kanyuma Jitjumnong oral presentation at ICACTE 2019 conference.

Noritsugu Kamata operates in the part of collection data, recommended system development, evaluation of the system, and wrote the paper .

All authors had approved the final version.

\section{ACKNOWLEDGMENT}

This research was supported by the Electrical Technology Education Department, Faculty of Industrial Education and Technology, King Mongkut's University of Technology Thonburi, Thailand.

\section{REFERENCES}

[1] L. Masterman, "Media education worldwide: Objectives, values and superhighways," Africa Media Review, vol. 10, pp. 61-75, 1996.

[2] A. Y. Lee, "Media education: Definitions, approaches and development around the globe," New Horizons in Education, vol. 58, no. 3, pp. 1-13, 2010.

[3] G. Nikitas, S. Bhattacharya, N. Vimalan, H. E. Demirci, N. Nikitas, and P. Kumar, "Wind power: A sustainable way to limit climate change," Managing Global Warming, Academic Press, pp. 333-364, 2019.

[4] R. L. Bain, R. P. Overend, and K. R. Craig, "Biomass-fired power generation," Fuel processing technology, vol. 54, no. 1, pp. 1-16, 1997.

[5] R. H. Williams and E. D. Larson, "Advanced gasification-based biomass power generation," Advanced Gasification-Based Biomass Power Generation, pp. 729-785, 1993.
[6] E. Hu, Y. Yang, A. Nishimura, F. Yilmaz, and A. Kouzani, "Solar thermal aided power generation," Applied Energy, vol. 87, no. 9, pp. 2881-2885, 2010.

[7] S. B. Elghali, M. E. H. Benbouzid, and J. F. Charpentier, "Marine tidal current electric power generation technology: State of the art and current status," IEEE International Electric Machines \& Drives Conference, vol. 2, May 2007.

[8] T. A. Adcock, S. Draper, and T. Nishino, "Tidal power generation - A review of hydrodynamic modelling," in Proc. the Institution of Mechanical Engineers, Part A: Journal of Power and Energy, vol. 229, no. 7, pp. 755-771, 2015

[9] J. Elmborg, "Critical information literacy: Implications for instructional practice," The Journal of Academic Librarianship, vol. 32, no. 2, pp. 192-199, 2006.

[10] C. Zarfl, A. E. Lumsdon, J. Berlekamp, L. Tydecks, and K. Tockner, "A global boom in hydropower dam construction," Aquatic Sciences, vol. 77 , no. 1 , pp. 161-170, 2015.

[11] J. B. Sheu, "Green supply chain management, reverse logistics and nuclear power generation," Transportation Research Part E: Logistics and Transportation Review, vol. 44, no. 1, pp. 19-46, 2008.

[12] D. B. Crawley, L. K. Lawrie, F. C. Winkelmann, W. F. Buhl, Y. J. Huang, C. O. Pedersen, and J. Glazer, "EnergyPlus: Creating a new-generation building energy simulation program," Energy and Buildings, vol. 33, no. 4, pp. 319-331, 2001.

[13] Y. Wakamatsu, "A citizens' conference on gene therapy in Japan: A feasibility study of the consensus conference method in Japan," Ai \& Society, vol. 13, no. 1-2, pp. 22-43, 1999.

[14] S. Tateno and H. M. Yokoyama, "Public anxiety, trust, and the role of mediators in communicating risk of exposure to low dose radiation after the Fukushima Daiichi Nuclear Plant explosion," Journal of Science Communication, vol. 12, no. 2, pp. A03, 2013.

Copyright $($ C 2020 by the authors. This is an open access article distributed under the Creative Commons Attribution License which permits unrestricted use, distribution, and reproduction in any medium, provided the original work is properly cited (CC BY 4.0).

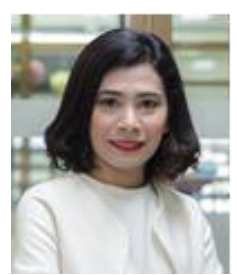

Kanyuma Jitjumnong is a lecturer at the Electrical Technology Education Department, Faculty of Industrial Education and Technology, King Mongkut's University of Technology Thonburi, Thailand. She received her bachelor and master degree in electrical engineering from King Mongkut's University of Technology Thonburi, Thailand, in 2006 and 2012, respectively. Currently, she is a doctoral student of philosophy program in learning innovation and technology at King Mongkut's University of Technology Thonburi, Thailand. Her current research includes robotics, electrical education and fiber optic.

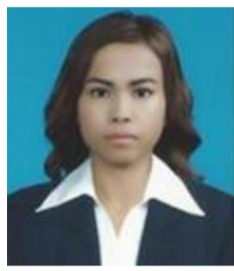

Pasapitch Chujai is a lecturer at the Electrical Technology Education Department, Faculty of Industrial Education and Technology, King Mongkut's University of Technology Thonburi, Thailand. She received her bachelor degree in computer science from Ramkhamhaeng University, Thailand, in 2000, the master degree in computer and information technology from King Mongkut's University of Technology Thonburi, Thailand, in 2004 and the doctoral degree in computer engineering, Suranaree University of Technology, Thailand, in 2015. Her current research includes ontology, recommendation system, time series, machine learning and imbalanced data classification.

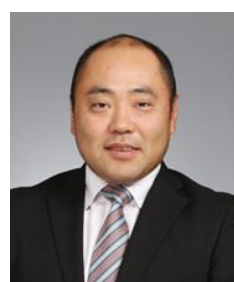

Noritsugu Kamata was born in Nagasaki, Japan, in 1979. He received the bachelor's degree in electrical engineering from the University of Tokyo Denki, in 2002. He became a research student at Tokyo Denki University, Tokyo, Japan, from 2002 to 2003. His research related to the crystal growth of the environment semiconductor, and Formation of $\beta-\mathrm{FeSi} 2$ thin films by partially ionized vapor deposition. He is currently a master's student in electrical engineering at Electrical Technology Education Department, Faculty of Industrial Education and Technology, King Mongkut's University of Technology Thonburi, Thailand. 